\title{
Indoor heating, house conditions, and health
}

\author{
I Gemmell
}

Many studies have shown a relation between damp housing and health, ${ }^{1-3}$ however, there has been relatively little research concerned with the effect of cold homes on health. Recent evidence has suggested that inability to keep a house warm is more strongly associated with health outcomes than is damp housing. ${ }^{4}$ This paper aims to assess the relation between housing characteristics and ill health focusing in particular on adequacy of indoor heating.

\section{Methods}

The subjects in this analysis were 858 respondents in the oldest cohort of the second sweep of the West of Scotland Twenty-07 Study, ${ }^{5}$ surveyed in 1991. The response rate for this wave was $82 \%$ and the average age of respondents was 59.

The survey recorded 13 variables concerning housing conditions. Some of these were from respondents' answers to questions such as how warm they felt in winter, others were objective opinions by the interviewer such as the type of house and others were subjective responses by the interviewer such as the condition of the house. All 13 housing variables were included in the analysis as categorical variables. A further 10 sociodemographic variables were used in the analysis.

Health outcome measures were restricted to chronic illness indicators derived from responses to standard questions used in the British General Household Survey. These were; the presence of one or more chronic condition(s), the presence of one or more limiting condition(s), and self assessed health. All the health outcomes were modelled as dichotomous variables in a logistic regression model. A dichotomous variable for self assessed health was created by contrasting the categories "fair" and "poor" against "good" and "excellent". All modelling was done using S-Plus 4.0 and the percentage of correctly predicted cases were $74 \%, 66 \%$, and $75 \%$ for each model respectively.

\section{Results}

The presence of one or more chronic condition(s) was reported in $71 \%$ of respondents; $52 \%$ reported that this condition limited their activities and $40 \%$ rated their health as either "fair" or "poor". All 23 explanatory variables
MRC Social and Public Health Sciences Unit, 4 Lilybank Gardens, Glasgow G11 8RZ, UK

Correspondence to: Dr Gemmell (i.gemmell@udcf.gla.ac.uk)

Accepted for publication 14 May 2001
Table 1 Significant variables from full logistic regression models

\begin{tabular}{|c|c|c|c|c|}
\hline Dependent variable & Explanatory variable & Response & $O R$ & $p$ Value \\
\hline \multirow{8}{*}{$\begin{array}{l}\text { Presence of one or more chronic } \\
\text { condition(s) }\end{array}$} & \multirow[t]{4}{*}{ Time of year } & Dec-Feb & 1.00 & - \\
\hline & & March-May & $1.50(0.97,2.31)$ & 0.068 \\
\hline & & June-Aug & $2.12(1.08,4.13)$ & 0.028 \\
\hline & & Sept-Nov & $2.20(0.40,12.13)$ & 0.360 \\
\hline & \multirow{4}{*}{$\begin{array}{l}\text { Anyone over } 16 \text { in full/ part time } \\
\text { employment } \\
\text { Tenure }\end{array}$} & Yes & 1.00 & - \\
\hline & & No & $2.00(1.20,3.34)$ & 0.008 \\
\hline & & Owner occupier & 1.00 & - \\
\hline & & Renter & $1.87(1.13,3.10)$ & 0.015 \\
\hline \multirow{11}{*}{$\begin{array}{l}\text { Presence of one or more limiting } \\
\text { condition(s) }\end{array}$} & \multirow{4}{*}{$\begin{array}{l}\text { Anyone over } 16 \text { in full/ part time } \\
\text { employment } \\
\text { Tenure }\end{array}$} & Yes & 1.00 & - \\
\hline & & No & $2.54(1.64,3.94)$ & $<0.001$ \\
\hline & & Owner occupier & 1.00 & - \\
\hline & & Renter & $1.78(1.14,2.78)$ & 0.011 \\
\hline & \multirow[t]{3}{*}{ Type of dwelling ${ }^{\star}$} & House & 1.00 & - \\
\hline & & Four in a block & $1.86(1.03,3.38)$ & 0.041 \\
\hline & & Flat & $1.48(0.70,3.12)$ & 0.305 \\
\hline & \multirow[t]{4}{*}{ House cold in winter } & Never & 1.00 & - \\
\hline & & Occasionally & $1.04(0.57,1.87)$ & 0.890 \\
\hline & & Often & $1.14(0.49,2.65)$ & 0.762 \\
\hline & & Most of the time & $3.48(1.33,9.06)$ & 0.011 \\
\hline \multirow{19}{*}{$\begin{array}{l}\text { Self assessed health classed as } \\
\text { 'fair' or 'poor' compared to } \\
\text { 'good' or 'excellent' }\end{array}$} & \multirow[t]{3}{*}{ Social class } & I \& II & 1.00 & - \\
\hline & & IIINM \& IIIM & $1.89(1.14,3.13)$ & 0.014 \\
\hline & & IV \& V & $1.85(0.99,3.46)$ & 0.052 \\
\hline & \multirow[t]{2}{*}{ Car owner in household } & Yes & 1.00 & - \\
\hline & & No & $1.56(1.00,2.43)$ & 0.047 \\
\hline & \multirow{4}{*}{$\begin{array}{l}\text { Anyone over } 16 \text { in full/ part time } \\
\text { employment } \\
\text { Tenure }\end{array}$} & Yes & 1.00 & - \\
\hline & & No & $1.80(1.14,2.83)$ & 0.011 \\
\hline & & Owner occupier & 1.00 & - \\
\hline & & Renter & $1.78(1.13,2.80)$ & 0.013 \\
\hline & \multirow[t]{6}{*}{ Winter bedroom heating type } & Central & 1.00 & - \\
\hline & & Gas fire & $0.67(0.26,1.72)$ & 0.412 \\
\hline & & Electric fire & $1.08(0.54,2.20)$ & 0.819 \\
\hline & & Solid & $0.37(0.03,5.08)$ & 0.455 \\
\hline & & Portable gas & $0.18(0.05,0.66)$ & 0.009 \\
\hline & & Don't heat & $0.70(0.39,1.25)$ & 0.233 \\
\hline & \multirow{4}{*}{ House cold in winter } & Never & 1.00 & - \\
\hline & & Occasionally & $0.84(0.46,1.53)$ & 0.567 \\
\hline & & Often & $1.64(0.70,3.86)$ & 0.255 \\
\hline & & Most of the time & $4.80(1.86,12.39)$ & 0.001 \\
\hline
\end{tabular}

* "House" indicates detached, semi-detached or terraced, "four in a block" indicates four flats in a block each flat having a separate entrance, "flat" indicates any other type of flat. 
were entered simultaneously into the multiple regression models. The results shown in table 1 are only for variables that were significant in the separate models.

Sociodemographic variables known to be associated with poor health were significant for each of the health measures; however, at least one housing variable was also significant in each model. Living in rented accommodation (local authority or private rented) was associated with increased odds of the presence of $1+$ chronic condition(s), 1+ limiting condition(s) and "fair" or "poor" self assessed health.

Respondents who reported feeling cold in winter "most of the time" were over three times more likely to suffer from a limiting condition and almost five times as likely to report "fair" or "poor" self assessed health. Type of bedroom heating was also associated with "fair" or "poor" self assessed health although the nature of this relation is not clear from this model. Two measures of dampness, respondents' assessment of dampness and interviewers assessment of dampness, were not significant in the multiple regression models.

The apparently counter-intuitive association between time of year and the presence of one or more chronic conditions may be attributable to the fact that the vast majority of interviews took place during February to May. Those respondents who were interviewed latterly may have postponed their interview because of ill health.

\section{Discussion}

This analysis has shown that, over and above socioeconomic factors and house conditions, inadequate home heating is associated with poor health in those aged 55-60. Although the observed association between ill health and inadequate home heating is not necessarily causal, living in a cold house will almost certainly exacerbate existing conditions and may lead to early mortality. Moreover, people living with a limiting condition may require relatively warmer housing because they are likely to be inactive for long periods of time.

Cold and dampness in homes are related ${ }^{4}$ and increased awareness of the importance of adequate affordable efficient methods of home heating could help reduce the number of people living in homes that are detrimental to their health. Further analysis in this area using objective measures of cold and damp housing would be beneficial.

Opinions and conclusions expressed in this paper are not necessarily those of the Scottish Executive Health Department.

Funding: this research was supported by the Chief Scientist Office of the Scottish Executive Health Department.

Conflicts of interest: none.

1 Packer C, Stewart-Brown S, Fowle SE. Damp housing and adult health: results from a lifestyle study in Worcester, England. F Epidemiol Community Health 1994;48:555-9.

2 Platt SD, Martin CJ, Hunt SM, et al. Damp housing, mould growth, and symptomatic health state. BMF 1989;298: 1673-8.

3 Martin CJ, Platt SD, Hunt SM. Housing conditions and ill health. BMF 1987;294:1125-7.

4 Evans J, Hyndman S, Stewart-Brown S, et al. An epidemiological study of the relative importance of damp housing in relation to adult health. F Epidemiol Community Health 2000;54:677-86.

5 Der G, Macintyre S, Ford G, et al. The relationship of household income to a range of health measures in three cohorts from the West of Scotland. European fournal of Public Health 1999;9:271-7. 